\title{
Exploring Enabling Interventions for Increasing Female Students' Access and Participation in Science, Technology, Engineering and Mathematics (Stem) Disciplines in Kenyan Public Universities
}

\section{Dr. Lucy Wandiri Mbirianjau ${ }^{1}$, Prof. Fatuma Chege ${ }^{2}$, Prof. Ibrahim Oanda ${ }^{3}$}

\author{
${ }^{1}$ Position: Lecturer Kenyatta University \\ Department: Educational foundations \\ Email:mbirianjau.lucy@ku.ac.ke \\ ${ }^{2}$ Position: Senior Lecturer Kenyatta University \\ Department: Educational foundations \\ Email: chege.fatuma@ku.ac.ke \\ ${ }^{3}$ Position: CODESRIA Senior Program Officer and \\ Head; Training Grants and Fellowship Program \\ Email:oandaibrahim@yahoo.com
}

\section{ABSTRACT}

Globally, studies continue to document disparities in women's access and participation in Science, Technology, Engineering and Mathematics (STEM) disciplines in the universities. Despite existence of policies at the national and institutional level, no single and clear road map exists on what set of interventions can best contribute to redressing this disparities. This study draws attention to the low participation of female students in STEM disciplines and especially in hard sciences in Kenyan public universities. Data for the study were collected in three public universities that were purposively sampled. Questionnaires, interviews, observations, content and documentary analysis were used as key instruments for data collection and research techniques. Data were analyzed both quantitatively and qualitatively. The study findings revealed that, despite the existing educational gender interventions, female students' enrolment and participation in STEM disciplines in the Kenyan public universities is $30 \%$ and less than $20 \%$ in hard sciences. The study also established that there exists a continued process of gender typing in the secondary school curriculum which students pick and is further manifested in the universities. This stereotype has created a false perception among female students that soft sciences are marketable for the female gender and are feminine compared to the hard sciences. Further there exists sociocultural and institutional barriers that affects female students' participation in STEM disciplines. The study recommends first, the need for government and universities to develop educational STEM policies and interventions to increase female participation in STEM disciplines. Second, the STEM curricula should be made gender responsive with integration of additional STEM female faculty members to act as mentors to female students. Appropriate STEM mentoring and career guidance should be enhanced at all levels of education and all educational stakeholders should be involved in minimising socio-cultural, institutional barriers and stereotypes on masculinity of STEM disciplines.

Key words: Gender, Interventions, Access, Participation, Science Technology Engineering and Mathematics (STEM) Disciplines.

\section{Background to the Study}

Globally, there is low access and participation of female students in Science, Technology, Engineering and Mathematics (STEM) disciplines at less than $30 \%$ and less than $25 \%$ in hard sciences (Mbirianjau, Chege, Oanda, 2016, Knight, Mappen \& Knight, 2011). The situation is worse in Africa whereby women participation in STEM disciplines is minimal, the greater gender imbalance is in Engineering, where one in four students was a woman in August 2010. In Kenya, female students constitute $27 \%$ in STEM disciplines (Onsongo, 2009, Mlambo, 2011).

In response to this problem, the Kenyan government and universities have put in place gender equity interventions in form of gender policies in education 
such as the Affirmative Action, engendering tertiary institutions, remedial disciplines, interfaculty transfers, financial aid and the self-sponsored programmes (SSP) to mainstream gender equity into STEM disciplines (Bunyi, 2003; Kapinga, 2010). Further, gender policies have been put in place to address sexual harassment, accommodation for female students, gender equity units, gender forums, gender committees and gender task forces. Finally, Kenyan universities offer gender studies courses, gender sensitization programmes, and gender policies are in place to raise the levels of women academicians and administrators to act as role models to female students (Bunyi, 2003; Kapinga, 2010; Mlambo, 2011).

The performance of girls in Kenya Certificate of Secondary Examination (KCSE) is a key determining factor for their access to University education and admission to STEM professional programmes which require high grades in Science subjects and Mathematics at KCSE level (Oanda \& Akudolu, 2010). The overall performance of girls in KCSE in 2011 and 2012 indicates that their performance was below that of boys. This means that few girls are able to compete for degree programmes in Kenya Universities in STEM disciplines most of which require a mean grade of A. For this reason, female students will not only be underrepresented in universities but more so in professional programmes (Chege \& Sifuna, 2006; Bunyi, 2008; Mugenda et al., 2010; Kapinga, 2010; Ohara, 2010 \& Oanda and Akudolu, 2010). Further, the society generally, is likely to suffer human resources deficits by neglecting a half of its population from Science and Technology (UNESCO, 2010).

\section{Importance of Women Participation in STEM}

Women should be scientifically and technologically literate if they are to fully participate in national development as equal citizens. Importantly, equal access to scientific and technological knowledge and skills by women is first a rights issue, in as much as education is a basic human right. Hill et al., (2013) argue that STEM disciplines should help students to be; problem-solvers, inventors, self-reliant, logical thinkers and technologically literate so as to apply technology appropriately. Accordingly, the United Nations, Economic and Social Council Report on the Status of Women(UNESCO) (2010) argues that STEM and innovation can be a tool with which to accelerate the achievement of vision 2030 and the internationally agreed development goals, including the Sustainable Development Goals. The Kenya vision 2030 considers gender inequality as one of the key development challenges facing the country. The country, therefore, has no choice but to make massive investment in STEM disciplines if all the set targets will be achieved. According to Forum for African Women Educationist (FAWE) (2014), to achieve the goals articulated in vision 2030, science and technology must be given due recognition and integrated in the structure of the economy(Kenya National Beaurea of Statistics) (KNBS, 2013).

\section{Statement of the Problem}

Despite the Kenya government's gender equity and equality policies and interventions that have been in existence since 2000 such as the Affirmative Action, introduction of self-sponsored programmes (SSP), offering of financial aids, engendering of tertiary institutions, gender sensitization and outreach programmes towards female participation in universities, there is still evidence of low access and participation of female students pursuing STEM disciplines in universities. This is due to the fact that the policies and interventions are not adequate and sustainable.

As the Kenyan society embraces technology as a tool for development, leaving out majority of the population from STEM disciplines has potential negative implications for attainment of an industrialised nation as proposed in Kenya's vision 2030. In addition, the continued low participation of women in STEM disciplines means that any benefits that have been shown to accrue from increased female participation in STEM, including contribution to increased productivity and socioeconomic development might be difficult to realize. The essence of this study therefore is to explore interventions for encouraging female students' access and participation in STEM disciplines in public universities in Kenya with a view to recommending viable interventions.

The study was guided by the following objectives:

i. Establish trends in female student's access to STEM disciplines in Kenyan public universities between years 2009 to 2013 .

ii. Establish female student's participation in STEM disciplines in Kenyan public 
universities between years 2009 to 2013 .

iii. Investigate institutional based limitations that continue to bar female student participation in STEM disciplines.

iv. Explore the gender responsiveness of the STEM curriculum to the learning needs of female students in STEM disciplines.

v. Evaluate existing educational policy interventions that influence trends in female participation in STEM disciplines in Kenyan public universities.

\section{Theoretical Framework}

This study was anchored on three theoretical postulates, namely; the social constructionist theory (SCOT), the pipeline model theory and the deficit model theory. The three theories complemented each other to explain female under representation in STEM disciplines emanating from societal construction of STEM discipline as masculine, STEM gendered preferences, institutional limitations, gender unfriendly STEM curriculum and inadequate educational policies and intervention in the universities. In the context of this study, the social constructionist theory explains low female participation in STEM disciplines as emanating from social construction of female students into stereotypically feminine disciplines, societal expectations and gender roles. In terms of gender responsiveness in STEM curriculum, the theory further explains low participation of female students in STEM disciplines (Berger \& Luckmann, 1966; Cockburn \& Ormrod, 1993 and Wajcman, 1991). The theory depicts that STEM disciplines and careers are masculine in nature. In reference to this study, pipeline and leakage models are metaphors that infer to the fact that female students pursuing STEM disciplines experience barriers (leakages) that hinder them from successfully pursuing STEM disciplines in the course of their studies (Kulis, Sicotte \& Collins, 2002 \& Settles; Cortina, Malley \& Stewart, 2006a). Like leakage found along the pipeline, female students pursing STEM disciplines experience institutional, sociocultural barriers, financial constraints and masculine STEM curriculum which affect their participation in STEM disciplines.

\section{RESEARCH METHODOLOGY}

This study adopted a descriptive survey research design entailing both qualitative and quantitative approaches. The design was appropriate for this study since the researcher was interested in establishing interventions to encourage female students' participation in science, technology, engineering and mathematics (STEM) disciplines in Kenyan public universities.

This study was carried out in three selected public universities in Kenya, namely; University of Nairobi (UoN), Jomo Kenyatta University of Agriculture and Technology (JKUAT) and Egerton University. The universities were purposively selected based on their strong traditions in STEM orientation, STEM facilities and high students' enrolments (KNBS, 2014). They provided contexts that were representative of the other public universities.

The target population for this study was 8475 third year-female students in STEM disciplines, registrars in charge of academic affairs, affirmative action directors, deans of faculties offering STEM disciplines, and female faculty members teaching STEM disciplines. In addition, a small group of male students in STEM disciplines were also targeted for their views on female participation in STEM disciplines. All these were sampled from the selected universities.

The study employed three sampling techniques, namely; purposive, stratified and simple random sampling. Purposive sampling was guided by the criteria of strength in STEM orientation, STEM facilities and student enrolments. Thus, three public universities; UoN, JKUAT and Egerton were selected out of the seven existing public universities at the time of the study. These three were considered representatives of the other public universities. STEM departments and all the key informants that included registrars, deans of STEM disciplines, STEM female faculties, directors of gender and affirmative action and female students pursuing STEM discipline were also purposively sampled. Second, stratified sampling was used to sample students pursuing STEM disciplines into five different areas, namely; Bachelor of Science, Engineering, Agriculture, Computer Science, and Health Sciences. Once stratified this way, random sampling was employed to select female students, and female faculty and deans in each strata. Simple random sampling ensures that each and every respondent has equal chances to participate in 
the study. All the registrars in charge of academic affairs and the affirmative action directors were included in the sample.

Primary data were collected using four main tools, namely; questionnaires, interviews, FGD and observation. Secondary data were sourced through documentary analysis framework of relevant institutional documents and content analysis guide of STEM teaching and learning materials. These tools generated both qualitative and quantitative data.

\section{PRESENTATION OF FINDINGS, INTERPRETATION AND DISCUSSION}

Objective One focussed on trends in female students' access in STEM disciplines in Kenyan public universities and trends in female students' access in STEM disciplines in the sampled public universities between 2009 to 2013. Female students are underrepresented in STEM disciplines in Kenyan public universities at less than $30 \%$ of STEM enrolments with lower enrolments in hard sciences. Higher enrolments were recorded in SSP mode of admission especially in soft sciences compared to hard sciences at $55.8 \%$ at JKUAT as a case institution. The above findings show that female students in SSP are more attracted to health sciences and computer disciplines compared to KUCCPS students. High enrolments in soft sciences are as a result of perceived stereotypes on the femininity of the disciplines and attractiveness to the job market. Hard sciences attract few female SSP STEM students despite the low cut-off point requirement by universities.

Objective Two sought to establish trends in female students participation in STEM disciplines in Kenyan public universities. Female students had lower completion $(66 \%)$ and progression rates (49\%). Similarly, only a third of female students in STEM disciplines graduated from the three sampled universities compared to males in all STEM disciplines. Hard sciences had the lowest female graduation trends compared to soft sciences. Low female graduation rates especially in hard sciences can be attributed to low STEM enrolments in the universities, the institutional barriers and challenges STEM female students encounter in their academic pursuits. High enrolment and graduation rates for female students in health sciences can be attributed to femininity of the discipline as a nurturing discipline, the job market, the societal expectations and the gender roles and lack of STEM policies, challenges and institutional-based barriers female students face in their pursuance of STEM disciplines.

In research objective three, the study established that there are institutional based limitations that continue to act as barriers to female student participation in STEM disciplines. First, female students had few female science and mathematics teachers role models as Science and Mathematics teachers in secondary are male dominated. Second, fewer females are admitted to national schools which have adequate facilities compared to day schools. The study established effectiveness of the secondary schools facilities can be linked to good performance in science subjects. Institutional based barriers that are manifested from lower levels of education especially the secondary level contribute to poor performance of female students in Science and Mathematics subjects which are mandatory requirement in STEM disciplines qualification in the universities.

Other institutional based limitations included lack of career guidance for the STEM disciplines female students were pursuing at the Universities. Female respondents indicated that they experience verbal violence/harassment and sexual harassment from male lecturers, fellow male students and sometimes male technicians. Further, respondents indicated that intimate relationships were too demanding and female students would also have to balance their studies with other family responsibilities affecting their participation in STEM disciplines. Finally, there are societal perceptions and stereotypes on female students venturing into STEM disciplines that affect their future life. The perceptions and stereotypes were on job opportunities, promotions at work, getting a spouse and family life. Further, stereotypes are transmitted through verbal interaction, content of STEM curriculum and general organization of teaching space.

The Fourth Objective established that there are gender biases in the STEM curriculum that affect female participation in STEM disciplines. Content analysis on STEM text books indicated perceived masculinity of the STEM textbooks that affected female students participation in STEM disciplines. Most STEM classes are male-dominated by both the STEM faculty and students. This disadvantages 
the female students pursuing STEM disciplines and affects their participation as they felt like outcasts in a male dominated world. Further the study noted that interaction of STEM lecturers, male and female students pursuing STEM disciplines in STEM classes was mutual.

Finally, the key findings from the Fifth Objective were that despite the Kenyan governments and universities gender equity policies and interventions, there is still low participation of female students in STEM disciplines. The existing educational policy interventions included SSP, financial aid, Affirmative Action policy, mentoring programmes and interfaculty transfers. First, the study further established that the existing Affirmative Action (AA) policy and financial aid have brought about minimal impact in female students access to STEM disciplines. Second, study reported that there are no educational STEM policy interventions in all the sampled universities and complementary educational policies and interventions. Third, there are few female Mathematics and Science teachers at secondary schools and same case applies to the female STEM faculty in the universities. For better performance in STEM disciplines, the study established the need for more female Science teachers in secondary schools and female STEM faculty to act as role models and to mentor the female students pursuing STEM disciplines. Fourth, there is need to strengthen Science Career guidance and mentoring programmes in both secondary schools and Universities. Negative attitude developed by female students and societal stereotypes on masculinity of STEM disciplines begins at lower levels of education. Fifth, appropriate career guidance training programmes for the high school teachers are important. Sixth, secondary schools Science learning facilities and text books are paramount for academic excellence in Mathematics and Science subjects. Seventh, gender friendly STEM curricular and learning environment will make the STEM disciplines more attractive to the female students. The respondents recommended that gender neutral learning environments with a feminist persuasion should be put in place. The eighth finding was that female students face many challenges such as sexual harassment, interruption through pregnancy and family responsibilities at the universities. Government and universities should develop STEM policies and interventions for the needy female STEM students who often drop out of university. Provision of hostels for nursing mothers and family planning services to female student in the universities are crucial. Gender based violence (GBV) by male lecturers and male students were reported by the respondents. Finally, universities should strengthen legal action against perpetuators and mechanism to address GBV in the universities and security within the campus and its environs.

\section{REFERENCES}

Berger, P. L. and T. Luckmann (1966). The Social construction of reality: A Treatise in the Sociology of Knowledge, Garden City, NY: Anchor Books.

Bunyi, G. (2008). Gender, education and EFA in Sub-Saharan Africa: progress, challenges and the way forward. The African Symposium, 8(1).

Bunyi, G. (2003). Interventions that increase enrolment of women in African tertiary institutions. A Case Study Prepared for a Regional Training Conference on Improving Tertiary Education in Sub-Saharan Africa: Things That Work!

Chege, F. \& Sifuna, D. (2006). Girls'and women's education in Kenya: gender perspectives and trends. Nairobi: UNESCO.

Cockburn, C. and Ormrod, S. (1993). Gender and technology in the making. London:

Sage.

FAWE. (2014). Strengthening gender research to improve girls' and women's education in Africa. Igarss 2014. Nairobi. doi:10.1007/s13398-0140173-7.2.

Hill, C., Corbett, C. and Rose, A. (2013). Why so few? Women in science technology engineering and mathematics. AAAUW.

Kapinga, B. (2010). Women access to science at the University of Dar es Salaam (UDSM), Tanzania. European Journal of Educational Studies, 2(3), 273-280.

KNBS. (2015). Kenya economic survey. The effects of brief mindfulness intervention on acute pain experience: An examination of individual difference (Vol. 1). Nairobi.

Knight, D., Mappen, F., \& Knight, S. (2011). A review of the literature on increasing the representation of women undergraduates in stem disciplines through civic engagement peda $=[\mathrm{p}$ [gogies. Science Ed, 3(1), 36-47. 
Retrieved from http://seceij.net/files/seceij/

winter10/knight.v3.pdf.

Kulis, S., Sicotte, D. and Collins, S. (2002). More than a pipeline problem: labour supply constraints and gender stratification across academic science disciplines. Research in Higher Education, 43(6), 657-690.

Mbirianjau, L. Chege, F \& Oanda, I.(2016), Exploring enabling interventions for increasing female students' access and participation in science, technology, engineering and mathematics (STEM) disciplines in Kenyan public universities, Nairobi, Kenya.

Mlambo, E. (2011). Science is for boys. The challenges of being a woman in science.

Mugenda, O., Kimani, E., Maina, L., and Wainaina, M. (2010). Female representation at various levels of education in Kenya: Identifying opportunities for policy, action and linkages. Nairobi: Longhorn Publishers.

Ohara, S. (2010). Higher education in Africa: Equity, access and opportunity. New York: Institute of International Education.

Onsongo, J. (2009). Affirmative action, gender equity and university admissions-Kenya,

Uganda and Tanzania. Review of Education, 7(1), 71-81. Retrieved from http://dx.doi. org/10.1080/14748460802700710.

Oanda, I. and Akudolu, L. (2010). Addressing gender inequality in higher education through targeted institutional responses: Field evidence from Kenya and Nigeria. In Higher Education in Africa: Equity, Access, Opportunity. Institute of International Education. New York: Institute of International Education.

UNESCO. (2010). SCIENCE. Paris.

Retrieved from http://unesdoc.unesco.org/ images/0018/001899/189958e.pdf.

Wajcman, J. (1991). Feminism confronts technology. Cambridge: Polity Press. 